\title{
Kampen om kroppen på liv og død
}

Artikkelen omhandler en ung kvinne med en aggressiv form for anorexia nervosa. Sykdomsutviklingen var rask og dramatisk. Allerede seks måneder etter sykdomsdebuten var det indikasjon for tvungen behandling, og det tilkom alvorlige og etter hvert livstruende somatiske komplikasjoner. Etter 2-3 års behandling var kvinnen fortsatt alvorlig syk - hun kastet opp, gikk ned i vekt og hadde elektrolyttforstyrrelser.

De alvorlige somatiske komplikasjonene som beskrives er heldigvis sjeldne, men sykehistorien er en påminnelse, om hvor alvorlig anorexia nervosa kan være, og at kampen om kroppen - om vekt og utseende - er en kamp på liv og død. Dette er en virkelig psykosomatisk lidelse, der alvorlighetsgraden uttrykkes både i somatiske og psykiske symptomer. Vekttap pga. vektfobi og misnøye med kroppen påvirker ulike organsystemer, og underernæring forverrer de psykiske symptomene. Behandlingen krever derfor bred kompetanse på flere områder og et godt samarbeid mellom ulike spesialiteter.

Selv om de alvorige komplikasjonene som her beskrives er sjeldne, er det grunn til å minne om at spiseforstyrrelser er en av de psykiske lidelsene som har høyere dødelighet. I en nyere studie fra Sverige fant man en standardisert mortalitetsratio ved anorexia nervosa på 6,2 (1). En studie fra USA viser noe lavere tall, men samtidig at mortaliteten er like høy ved andre typer spiseforstyrrelser (2).

Stokke og medarbeideres artikkel gir også grunnlag for refleksjoner omkring ulike problemstillinger knyttet til de vanskelige aller sykeste pasientene. Siden tusenårsskiftet har det vært satset bredt på å bedre behandlingstilbudet til denne pasientgruppen, både i volum og kvalitet. I alle helseregioner er det nå spesialiserte behandlingstilbud innenfor psykisk helsevern, både døgn- og dagbehandling og poliklinisk behandling. Er det mulig å hindre utvikling av de alvorligste formene for anoreksi, og kan økt kompetanse bidra til dette?

Pasienter med spiseforstyrrelser kan være en utfordring på mange måter. Liten sykdomsinnsikt og varierende motivasjon for endring hos en alvorlig syk person kan være vanskelig å forstå. Hvis pasienten unndrar seg vektkontroll eller andre undersøkelser som anses som en nødvendig del av i en forsvarlig oppfølging, stilles legen i en vanskelig situasjon i skjæringspunktet mellom kravet om forsvarlig pasientbehandling og ivaretakelse av pasientens autonomi. Frykten for å ødelegge en skjør, nødvendig allianse kan gi spillerom for pasientens forhandlingstaktikk, noe som ikke er til vedkommendes beste. I møtet med pasienten er det derfor viktig å ha noen «non-negotiables», dvs. klare rammer og avtaler der enkelte elementer ikke kan forhandles. Man kan diskutere når og hos hvem, men ikke om pasienten skal veies.

Pasientens autonomi må settes opp mot forsvarlighetskriteriet. Dette gjelder også bruk av tvang. Selv om motivasjon er en viktig forutsetning for et godt behandlingsresultat, kan tvungen innleggelse og tvungen behandling i enkelte tilfeller være de rammene og grensene pasienten trenger for ikke å tape i kampen om livet (3).

Kompetanse er en funksjon av både kunnskap og erfaring. De alvorligste komplikasjonene er sjeldne, men organiseringen av behandlingstilbudet for denne pasientgruppen må ivareta kompetansen også på dette området. I tillegg til kompetanse kreves det også et nært og forpliktende samarbeid mellom de involverte avdelinger.

\section{Sigrid Bjørnelv \\ bjbjoe@online.no \\ Psykiatrisk klinikk \\ Sykehuset Levanger \\ 7600 Levanger}

Oppgitte interessekonflikter: Ingen

Litteratur

1. Crow SJ, Peterson CB, Swanson SA et al. Increased mortality in bulimia nervosa and other eating disorders. Am J Psychiatry 2009; 166: 1342-6.

2. Papadopoulos FC, Ekbom A, Brandt L et al. Excess mortality, causes of death and prognostic factors in anorexia nervosa. Br J Psychiatry 2009; 194 $10-7$.

3. Syse A. Psykisk helsevernloven: Lov 2. juli 1999 nr. 62 om etablering og gjennomføring av psykisk helsevern: kommentarutgave med forskrifter. Oslo: Gyldendal Akademisk, 2004.

Manuskriptet ble mottatt 5.9. 2010 og godkjent 18.10. 2010. Medisinsk redaktør Erlend Hem. 